\title{
オフ期の栄養教育が減量期の女子新体操選手の 食事改善に及ほす影響
}

\author{
横山 友里*1，山田美恵子*2，木皿久美子*2，橋爪みすず*3,*4， \\ 小久保友貴*5, 日田安寿美*6, 多田 由紀*6, 吉崎 貴大*1, \\ 砂見 綾香*1, 石崎 朔子*2, 川野＼cjkstart因*6
}

*1東京農業大学大学院農学研究科 ${ }^{* 2}$ 日本女子体育大学体育学部 $* 3$ 伊那西高等学校 $* 4$ 松本大学大学院健康学科 *5 金城学院大学生活環境学部食環境栄養学科 $* 6$ 東京農業大学応用生物科学部栄養科学科

【目的】大学女子新体操選手を対象にオフ期に実施する栄養教育が減量期のたんぱく質摂取量の低下を防ぎ, 貧血発現が予防できる可 能性を検討する。

【方法】2009年 6 月（減量期前）か52010年 8 月（減量期後）まで協力の得られた14名を対象とした。2010年 2 月から4月上旬（オフ期） に貧血予防のためのたんぱく質捸取の重要性を講話し, 食材購入や調理実習, 献立作成演習などを体験させた。調査項目は体重, 体脂 肪率, 貧血指標, エネルギー, たんぱく質, たんぱく質を多く含む食品群の摂取量とし, 2009年度と2010年度の減量期前と減量期後に 計 4 回調査した。2009年度の各值は教育実施前の対照値とした。

【結果】減量期前の身体特性, 未梢血液一般検査, 食物摂取状況は体重, BMI, 除脂肪体重, RBC を除き2009年度と2010年度との間に 有意な差はみられなかった。2009年度のたんぱく質エネルギ一比率, 豆類, 卵類摂取量は, 減量期前に比べ減量期後が有意に減少した が, 2010年度は体脂肪率が有意に減少し, 卵類摂取量は増加した。減量期の变化量は, 教育を行った2010年度が2009年度に比べて体脂 肪率は有意な低值を示し，たんぱく質摂取量，たんぱく質エネルギー比率，豆類，卵類摂取量は有意な高值を示した。しかし，Htを 除く貧血指標には有意な変化を及ぼすことはなかった。

【結論】オフ期の栄養教育はたんぱく質摂取量の低下を抑制するものの, Ht を除く貧血指標には影響を及ぼさないことが示唆された。 栄養学雑誌, Vol.71 No.1 29-36 (2013)

キーワード：栄養教育, 新体操, 減量期, たんぱく質摂取量, 貧血発現

\section{I. 緒言}

多くのスポーツ選手は勝つことを目指して昼夜, 計画 的に練習を行い，その内容は一年間のトレーニング時期 によって異なっている。試合が繰り返される「試合期」 とその前には勝つための専門的体力（身体づくり）と専 門的技術の獲得を目指す「準備期」があり, 試合が終っ た後は心と身体を試合の緊張から解放させ, 次なる試合 に向けて身体を整える「移行期（いわゆるオフ期）」があ る。新体操の場合は, 5 月に東日本学生新体操選手権大 会, 8 月中旬から 12 月までが全日本学生新体操選手権大 会や全日本新体操選手権大会, さらに各種の世界大会な どが繰り返される「試合期」であり，6月から 8 月上旬 までの 2 ヶ月間は「準備期」である。準備期は同時に試 合に向けた減量を余儀なくされる「減量期」でもある。 そして，オフ期は 1 月から 4 月上旬とされるのが一般的 である。

新体操はまた, 1 分 30 秒 (個人) から 2 分 30 秒（団 体）という短時間内でロープやフープ, ボール, クラブ,
リボンの 5 種類の手具操作技術の精度を競う採点競技で あり，見た目にも美しい容姿は重要な得点要素である。 そのため選手の中には理想の体型を目指して幼い時から 減量を日常的に繰り返すものが多く, 極端に少ないエネ ルギー摂取量とそれに伴う多くの栄養素の摂取不足，欠 食や偏食, 菓子類の過剩摂取といった食生活上の問題 点 ${ }^{1)}$, さらには, 摂食障害, 鉄欠乏性貧血や月経異常と いった競技力に影響を及ぼす健康課題を抱える選手が多 ${ }^{2,3)}$, 健康的に減量できる方法について食生活面からア ドバイスする必要が求められている。減量期はエネル ギー摂取量の低下に伴い多くの栄養素も低下する。我々 は既に大学女子新体操選手の減量期の貧血発現と食生活 との関わりを調べ, 試合直前のいわゆる減量期後の貧血 発現には減量期間中に摂取するたんぱく質摂取量の多寡 が関わることを明らかにした ${ }^{4)}$ 。すなわち, 減量期前に体 内鉄栄養状態が正常である新体操選手では，2 2 ケ月間の 減量期間中の習慣的なたんぱく質摂取量が体重当たり $1.4 \mathrm{~g}$ を維持できる場合は鉄不足状態を回避できることが 明らかとなった ${ }^{4)}$ 。

連絡先：川野 因 $7156-8502$ 東京都世田谷区桜丘1-1-1 東京農業大学応用生物科学部栄養科学科 電話 03-5477-2453 FAX 03-5477-2453 E-mail ylkawano@nodai.ac.jp 
一方，これまでにも新体操選手を対象に減量期前に一 過性の栄養教育を実施し, その効果を検証・報告してき たものの, 食物摂取状況に有意な変化を導くことはでき なかった ${ }^{5,6)}$ 。また, 大学選手は親元から離れて一人暮ら しをする学生が多く, 大学入学までの食体験がそしく, 入学後はコンビニエンスストアやスーパーマーケットで 食事を整える選手が多く，自炊のできない選手が多いこ とが報告されている ${ }^{7)}$ 。減量期は試合を直前に控え, 試合 への意識が高まっている時期であることから, 減量期直 前にたんぱく質摂取の重要性を伝えても食生活でこれを 実践することは難しいと考え, 時間的にも精神的にも余 裕のあるオフ期に食生活にかかわる教育を実施すること とした。

すなわち, 本研究では, 大会シーズンも終わり, 次の 試合までの休養期間となるオフ期に減量期のたんぱく質 摂取量の低下を防ぐことを目的に栄養教育を実施し，そ の効果を検討することとした。

\section{II. 方 法}

\section{1. 対 象者}

大学新体操部に所属している女子学生で本研究への参 加に同意が得られた14名を対象者とした。対象者の競技 レベルは高く, 東日本学生新体操選手権大会や全日本学 生新体操選手権大会において個人戦および団体戦ともに 上位の成績を収めるチームである。研究を行うにあたっ て, あらかじめ東京農業大学および日本女子体育大学 「人を対象とする実験・調査等に関する倫理委員会」に研 究計画書を提出し承認を得るとともに, 選手に対しては 予想される危険性などを十分に説明し, 本人または保護 者から文書による同意を得た。

\section{2. 栄養教育と評価のスケジュール}

栄養教育と評価のスケジュールを図 1 に示す。調査研 究期間は2009年 6 月から 2010 年 8 月までとし, いずれも
6 月から 8 月が試合前 2 ケ月間の減量期であり，6月を 減量期前, 8 月を減量期後と定義するとともに各種の測 定を行った。栄養教育は2010年の 2 月から 4 月上旬まで 計 4 回実施し（表 1 ），栄養教育の効果は栄養教育を行わ なかった2009年度を対照として評価した。

この間，2009年 8 月には全日本学生新体操選手権大会, 9 月には世界新体操選手権大会, 10月には全日本新体操 選手権大会, 12 月には東日本学生新体操新人・交流大会 などが，翌2010年 5 月には東日本学生新体操選手権大 会, 8 月には全日本学生新体操選手権大会が開催された。

\section{3 . 栄養教育内容}

本研究では減量期のたんぱく質摂取量の低下を抑制し 貧血発現を予防することを長期教育目標に，短期アウト カム評価指標には一日のたんぱく質摂取量, たんぱく質 エネルギー比率, さらにはたんぱく質を多く含んだ食品 群の平均摂取量を用い, 減量期にこれらを低下させない ことを短期教育目標とした。教育形式は, 講義と実習や 演習といった体験型の教育方法（スーパーマーケットで の買い物，調理実習，献立作成演習）を用いた。

栄養教育の内容は表 1 に示すとおりであり，大会シー ズンが終わり，次の試合までの長期休養期間となるオフ 期に，(1)減量期のたんぱく質摂取と貧血発現とのかかわ りに関する情報提供, (2)スーパーマーケットでの食品選 択, (3)調理体験, さらには, (4) 1 食分の献立を考えると いった栄養教育を 4 回にわたって実施した。まず第 1 回 目は, 減量期のたんぱく質摂取量が貧血発現に密接に関 わること4）を講義した。すなわち，減量期には 1 日あた りのたんぱく質摂取量の低下がへモグロビン濃度の低下 と密接に関わること, 減量に伴うエネルギー摂取量の低 下は同時にたんぱく質摂取量を低下させること，これを 防ぐためには意識してたんぱく質を多く含んだ食品をと る必要があるといった情報提供に加え, 調理が簡単で, 安価に購入でき, かつ, 保存性が高くたんぱく質を多く 含む食品（卵や納豆，豆腐，魚肉ソーセージなど）を紹

2009年 2010年

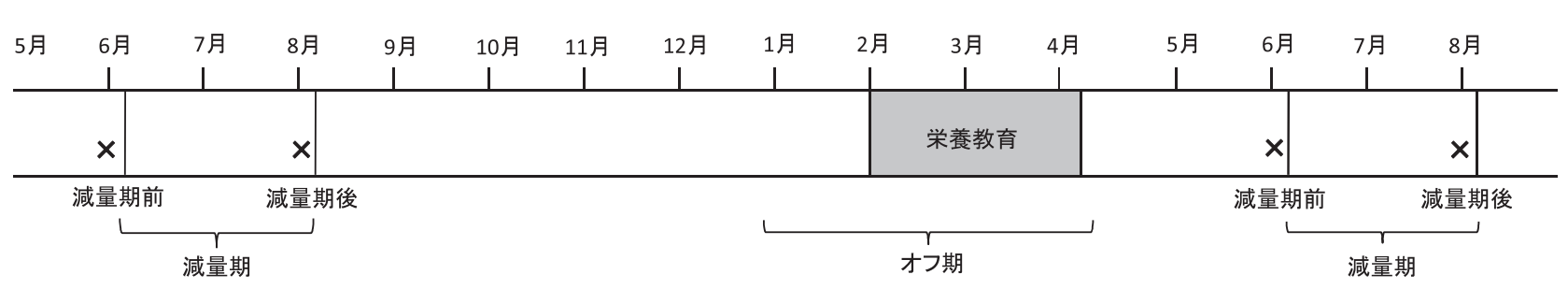

図 1 栄養教育と評価のスケジュール

$\times$ 減量期前求よび減量期後の身体計測, 未梢血液一般検查, 食物摂取状況調查時期。2009年度の 6 月から 8 月にかけての減量期を対 照に2010年度の 6 月から 8 月の減量期のたんぱく質およびたんぱく質を多く含む食品群の摂取量, 貧血指標を評価した。この間, 2010 年 2 月から 4 月上旬のオフ期に 4 回にわたる栄養教育を実施した。 
表 1 栄養教育の内容

\begin{tabular}{|c|c|c|c|}
\hline 実施回数 & 実施月 & 集団教育方法 & 内 \\
\hline 第 1 回 & 2 月 & $\begin{array}{l}\text { 講義掞よび } \\
\text { 体験学習 }\end{array}$ & $\begin{array}{l}\text { 1) 新体操選手の貧血発現と食事-たんぱく質の重要性（講義） } \\
\text { 2) たんぱく質摂取量を増加させるための市販食品の活用法（講義） } \\
\text { 3) スーパーでの買い物（体験学習） }\end{array}$ \\
\hline 第 2 回 & 2 月 & 体験学習 & $\begin{array}{c}\text { 調理実習（たんぱく質摂取量の増加を意識した料理） } \\
\text { メニュー：かきたまうどん（卵，豚肉), ゆでブロッコリー } \\
\text { 1 食あたりのたんぱく質摂取量 } 26.5 \mathrm{~g}\end{array}$ \\
\hline 第 3 回 & 3 月 & 体験学習 & $\begin{aligned} \text { 調理実習（たんぱく質摂取量の増加を意識した料理） } \\
\text { メニュー：キムチ雑炊 (卵, 鶏ささみ), ひじきの煮物, 切干大根 } \\
\text { 1 食あたりのたんぱく質摂取量 } 19.8 \mathrm{~g}\end{aligned}$ \\
\hline 第 4 回 & 4 月 & 体験学習 & $\begin{array}{l}1 \text { 食分の献立作成 } \\
\text { 食事づくり（食材購入，調理，配食，片づけ） }\end{array}$ \\
\hline
\end{tabular}

介する集団栄養教育を実施した。そして, 講義終了後に はスーパーマーケットへ出かけ, 自分たちの昼食を購入 し, 主食・主菜・副菜が揃っていること, たんぱく質を 多く含む食品を購入していることを確認させた。第 2 回 目, 第 3 回目は卵や豚肉, 鶏肉などを使った調理実習を 行った。調理実習には食物や栄養に関する知識や調理技 術の定着が期待できるとされている ${ }^{8)}$ 。そのため, 一人暮 らしでかつ調理経験のそしい対象者にとっては効果的な 教育方法のひとつと考えた。第 4 回目は, 選手自身に合 宿時の献立を 1 食分作成させた。エネルギーはじめ栄養 計算は選手にとっては難しい作業となるため, 著者らが エネルギー目標量（エネルギー $600 \mathrm{kcal} /$ 食，たんぱく 質 $25 \mathrm{~g}$ /食）と対応させて分量を決めた。また, 出来上 がった献立のチェックポイントは(1)主食・主菜・副菜が 揃っている，(2)たんぱく質を多く含んだ食品が使われて いる, (3)調理の簡便さ, (4)安全性, (5)衛生的に料理でき ることとし, 結果は選手に返却した。合宿期間中の食事 準備などは全てを選手が分担してこれにあたり，献立に 則った食材量の購入と調理，盛り付けを行った。

\section{4. 調 査項目}

全日本学生新体操選手権大会にむけて減量を開始する 前（減量期前）と大会の直前（減量期後）それぞれに身 体計測, 末梢血液一般検査, 食物摂取状況調査を実施し た。

\section{1 ) 身体計測}

選手は採血を実施する日の午前 7 時半に早朝空腹条件 下で測定会場に集合し，身長，体重，体脂肪率を測定し た。身長はヤガミ社製ハンドル大型身長計 YL-65を用い， 体重は TANITA 社製 TBF-310 用いて測定した。また, 身長と体重の結果をもとに body mass index（BMI）を算 出した。体脂肪率は栄研式皮脂厚計を用いて推定した。 すなわち，上腕背部および肩甲骨下部の皮下脂肪厚を同 一担当者が 3 回測定し, その平均值をそれぞれの平均皮
下脂肪厚とした。その後, 体密度「1.0913-0.00116（上 腕背部平均 + 肩甲骨下部平均)」を算出し, Siri の式「体 脂肪率 $=495 /$ 体密度 -450$\rfloor^{9)}$ を用いて体脂肪率を算出 した。

2 ）末梢血液一般検查

選手は起床後，12時間以上の空腹条件を維持したまま 測定会場に集合した。その後, 午前 8 時より医師管理下 で有資格者が正肘皮静脈より採血を実施した。血液分析 は(株)メディカルラボに依頼し，検査項目は赤血球数 $(\mathrm{RBC})$, ヘモグロビン $(\mathrm{Hb})$ ，ヘマトクリット $(\mathrm{Ht})$, 平 均赤血球容積 $(\mathrm{MCV})$, 平均赤血球血色素量 $(\mathrm{MCH})$, 平均赤血球血色素濃度 (MCHC) とした。

3 ）食物摂取状況調査

食物摂取状況は調査日から直近 $1 \sim 2$ ケ月間前の習慣 的な摂取量を把握することを目的に，5訂増補日本標準 食品成分表に準拠した半定量食物摂取頻度調査票（エク セル栄養君 FFQg 建帛社) ${ }^{10 ）}$ を用いて調査した。回収に あたり，著者らが個別に未記入や誤記入の有無を確認し て，精度を高めた。

\section{5. 統計解析}

結果はすべて平均值 標準偏差で示した。2009年度と 2010年度の減量期前および減量期後の身体計測，末梢血 液一般検査および食物摂取状況調査の結果の比較には, まず各変数に Shapiro-Wilk の正規性の検定を行った後, 正規性のある連続変数には対応のある $t$ 検定を，正規性 のない連続変数には Wilcoxonの符号付き順位和検定を用 いた。また，2009年度と2010年度の減量期前と減量期後 の変化量を減量期前の各值を共変量として調整した上で, 対応のある $t$ 検定または Wilcoxon の符号付き順位和検定 を用いて比較した。統計処理には, IBM SPSS Statistics 19 for Windows（IBM 社）を用い，有意水準は $5 \%$ 未満 （両側検定）とした。 


\section{III. 結 果}

\section{1. 減量期前の比較}

減量期前の体重, BMI, 除脂肪体重は2010年度が2009 年度に比べて有意に高值を示した（表 2 , 体重 : $p=$ 0.005 , BMI $: p=0.008$, 除脂肪体重 $: p<0.001)$ 。しか し, 体脂肪率には有意な差はみられなかった。また RBC は2010年度が2009年度に比べて有意に低值を示したもの の $(p=0.011), \mathrm{Hb}, \mathrm{Ht}, \mathrm{MCV}, \mathrm{MCH}, \mathrm{MCHC}$ には有 意な差はみられなかった。エネルギー, たんぱく質, 鉄 摂取量, さらにはたんぱく質を多く含む食品群別摂取量 においても両年度間に有意な差はみられなかった。

\section{2. 減量期前後の比較}

2009年度および2010年度ともに, 体重, BMI, 除脂肪 体重, RBC, Hb, Ht, MCV, MCH, MCHCは, 減量 期前と減量期後の間に有意な差はみられなかった（表
2 )。体脂肪率は，2010年度においてのみ減量期後が減量 期前に比べて有意に減少した $(p=0.002)$ 。食物摂取状況 では，エネルギー，たんぱく質，鉄摂取量は減量期前後 間で両年度とも有意な差がみられなかった。たんぱく質 エネルギー比率は2009年度が減量期前に比べて減量期後 で有意に減少し $(p=0.023) ， 2010$ 年度は減量期前後で有 意な差がみられなかった。また，豆類，卵類の摂取量は 2009年度が減量期前に比べて減量期後で有意に減少した のに対し，2010年度は卵類が減量期前に比べて減量期後 で有意に増加した。魚介類や肉類, 乳類の摂取量は2009 年度，2010年度ともに有意な差はみられなかった。

\section{3. 減量期変化量の比較}

減量期の各指標の変化量を減量期前の各值を共変量と して調整した上で，2009年度と2010年度を比較した（表 3 )。

減量期の身長, 体重, BMI, 除脂肪体重, RBC, $\mathrm{Hb}$,

表 2 減量期前後の身体特性, 未梢血液一般検査, 食物摂取状況の比較

\begin{tabular}{|c|c|c|c|c|c|c|c|c|}
\hline & & \multicolumn{3}{|c|}{ 2009年度（教育無） } & \multicolumn{3}{|c|}{ 2010年度（教育有） } & \multirow{2}{*}{$\begin{array}{c}\begin{array}{c}\text { 群間比較 } \\
\text { (減量期前) }\end{array} \\
p^{\ddagger}\end{array}$} \\
\hline & & 減量期前 & 減量期後 & $p^{\dagger}$ & 減量期前 & 減量期後 & $p^{\dagger}$ & \\
\hline \multicolumn{9}{|l|}{ 身体特性 } \\
\hline 身長 & $(\mathrm{cm})$ & $161.7 \pm 3.5$ & $161.7 \pm 3.6$ & 0.72 & $162.0 \pm 3.5$ & $161.7 \pm 3.8$ & 0.25 & 0.096 \\
\hline 体重 & $(\mathrm{kg})$ & $50.2 \pm 4.5$ & $49.8 \pm 4.7$ & 0.16 & $51.7 \pm 4.4$ & $51.3 \pm 4.1$ & 0.23 & 0.005 \\
\hline BMI & $\left(\mathrm{kg} / \mathrm{m}^{2}\right)$ & $19.2 \pm 1.4$ & $19.0 \pm 1.3$ & 0.13 & $19.7 \pm 1.5$ & $19.6 \pm 1.4$ & 0.54 & 0.008 \\
\hline 体脂肪率 & $(\%)$ & $15.8 \pm 2.6$ & $15.8 \pm 3.0$ & 1.0 & $14.8 \pm 3.6$ & $13.8 \pm 3.1$ & 0.002 & 0.094 \\
\hline 除脂肪体重 & $(\mathrm{kg})$ & $42.2 \pm 3.3$ & $41.8 \pm 3.2$ & 0.089 & $44.0 \pm 3.4$ & $44.2 \pm 3.2$ & 0.45 & $<0.001$ \\
\hline \multicolumn{9}{|l|}{ 末梢血液一般検査 } \\
\hline $\mathrm{RBC}$ & $\left(\times 10^{4} / \mu l\right)$ & $421.4 \pm 36.8$ & $417.0 \pm 39.0$ & 0.39 & $402.8 \pm 34.1$ & $408.5 \pm 31.9$ & 0.29 & 0.011 \\
\hline $\mathrm{Hb}$ & $(\mathrm{g} / \mathrm{d} l)$ & $12.8 \pm 1.5$ & $12.5 \pm 1.4$ & 0.13 & $12.2 \pm 1.4$ & $12.2 \pm 1.3$ & 0.75 & 0.069 \\
\hline $\mathrm{Ht}$ & $(\%)$ & $37.3 \pm 3.5$ & $36.8 \pm 3.7$ & 0.35 & $35.6 \pm 3.3$ & $36.5 \pm 3.0$ & 0.068 & 0.059 \\
\hline $\mathrm{MCV}$ & (fl) & $89.0 \pm 7.5$ & $88.3 \pm 6.7$ & 0.28 & $89.0 \pm 6.8$ & $89.1 \pm 7.3$ & 0.83 & 1.0 \\
\hline $\mathrm{MCH}$ & $(\mathrm{pg})$ & $30.6 \pm 3.4$ & $30.0 \pm 2.9$ & 0.12 & $30.2 \pm 3.2$ & $30.1 \pm 3.1$ & 0.75 & 0.33 \\
\hline $\mathrm{MCHC}$ & $(\%)$ & $34.4 \pm 1.3$ & $34.0 \pm 0.8$ & 0.096 & $34.0 \pm 1.2$ & $33.6 \pm 1.2$ & 0.055 & 0.27 \\
\hline \multicolumn{9}{|l|}{ 食物摂取状況 } \\
\hline エネルギー & (kcal) & $2,264 \pm 677$ & $2,133 \pm 525$ & 0.37 & $2,091 \pm 463$ & $2,028 \pm 454$ & 0.51 & 0.18 \\
\hline たんぱく質 & $(\mathrm{g})$ & $67.4 \pm 19.7$ & $59.3 \pm 14.3$ & 0.082 & $60.3 \pm 15.5$ & $61.0 \pm 15.0$ & 0.79 & 0.21 \\
\hline $\begin{array}{l}\text { 体重当たり } \\
\text { たんぱく質量 }\end{array}$ & $(\mathrm{g} / \mathrm{kg})$ & $1.36 \pm 0.45$ & $1.22 \pm 0.37$ & 0.10 & $1.18 \pm 0.36$ & $1.20 \pm 0.33$ & 0.73 & 0.074 \\
\hline 鉄 & $(\mathrm{mg})$ & $8.8 \pm 3.2$ & $7.4 \pm 2.5$ & 0.091 & $7.2 \pm 2.0$ & $6.9 \pm 1.8$ & 0.42 & 0.73 \\
\hline $\begin{array}{l}\text { たんぱく質 } \\
\text { エネルギー比率 }\end{array}$ & $(\%)$ & $12.1 \pm 2.2$ & $11.2 \pm 1.6$ & 0.023 & $11.6 \pm 1.7$ & $12.1 \pm 1.7$ & 0.23 & 0.88 \\
\hline 豆類 & $(\mathrm{g})$ & $77.1 \pm 71.8$ & $39.6 \pm 26.9$ & 0.039 & $51.1 \pm 43.9$ & $45.7 \pm 37.6$ & 0.62 & 0.21 \\
\hline 魚介類 & $(\mathrm{g})$ & $25.1 \pm 28.5$ & $19.1 \pm 25.3$ & 0.27 & $19.7 \pm 22.1$ & $23.8 \pm 27.6$ & 0.30 & 0.35 \\
\hline 肉類 & $(\mathrm{g})$ & $65.3 \pm 36.3$ & $56.7 \pm 35.5$ & 0.41 & $62.5 \pm 37.3$ & $69.8 \pm 43.2$ & 0.59 & 0.82 \\
\hline 卵類 & $(\mathrm{g})$ & $28.1 \pm 19.1$ & $16.8 \pm 15.8$ & 0.045 & $24.5 \pm 13.1$ & $32.1 \pm 16.5$ & 0.013 & 0.48 \\
\hline 乳類 & $(\mathrm{g})$ & $222.1 \pm 80.1$ & $259.0 \pm 97.6$ & 0.27 & $219.3 \pm 119.7$ & $207.6 \pm 87.8$ & 0.58 & 0.43 \\
\hline
\end{tabular}

值は平均值 \pm 標準偏差 $(n=14)$

$\dagger$ 対応のある $t$ 検定または Wilcoxon の符号付き順位和検定 : 各年度の減量期前と減量期後の比較

‡ 対応のある $t$ 検定または Wilcoxon の符号付き順位和検定 : 2009年度と2010年度の減量期前の比較 
表 3 減量期の変化量の比較

\begin{tabular}{llccc}
\hline & & 2009 年度 (教育無) & 2010 年度 (教育有) & $p^{\dagger}$ \\
\hline \hline 身長 & $(\mathrm{cm})$ & $0.1 \pm 0.4$ & $-0.2 \pm 0.9$ & 0.30 \\
体重 & $(\mathrm{kg})$ & $-0.4 \pm 1.2$ & $-0.4 \pm 1.1$ & 0.95 \\
$\mathrm{BMI}$ & $\left(\mathrm{kg} / \mathrm{m}^{2}\right)$ & $-0.2 \pm 0.4$ & $-0.1 \pm 0.5$ & 0.50 \\
体脂肪率 & $(\%)$ & $0.0 \pm 1.9$ & $-1.1 \pm 0.8$ & 0.011 \\
除脂肪体重 & $(\mathrm{kg})$ & $-0.4 \pm 0.8$ & $0.2 \pm 0.9$ & 0.16 \\
\hline $\mathrm{RBC}$ & $\left(\times 10^{4} / \mu l\right)$ & $-4.6 \pm 18.4$ & $5.7 \pm 17.7$ & 0.075 \\
$\mathrm{Hb}$ & $(\mathrm{g} / \mathrm{d} l)$ & $-0.3 \pm 0.7$ & $0.0 \pm 0.7$ & 0.093 \\
$\mathrm{Ht}$ & $(\%)$ & $-0.5 \pm 1.9$ & $0.9 \pm 1.5$ & 0.006 \\
$\mathrm{MCV}$ & $(\mathrm{fl})$ & $-0.7 \pm 2.1$ & $0.0 \pm 1.2$ & 0.27 \\
$\mathrm{MCH}$ & $(\mathrm{pg})$ & $-0.6 \pm 1.1$ & $-0.1 \pm 0.8$ & 0.20 \\
$\mathrm{MCHC}$ & $(\%)$ & $-0.4 \pm 0.4$ & $-0.4 \pm 0.6$ & 0.97 \\
\hline エネルギー & $(\mathrm{kcal})$ & $-130.9 \pm 399.9$ & $-63.5 \pm 319.8$ & 0.61 \\
たんぱく質 & $(\mathrm{g})$ & $-8.0 \pm 11.5$ & $0.6 \pm 8.8$ & 0.049 \\
鉄 & $(\mathrm{mg})$ & $-1.4 \pm 2.2$ & $-0.4 \pm 1.4$ & 0.25 \\
体重当たりたんぱく質量 & $(\mathrm{g} / \mathrm{kg})$ & $-0.1 \pm 0.3$ & $0.0 \pm 0.2$ & 0.074 \\
たんぱく質エネルギー比率 & $(\%)$ & $-0.7 \pm 0.9$ & $0.4 \pm 1.3$ & 0.010 \\
\hline 豆類 & $(\mathrm{g})$ & $-37.5 \pm 24.6$ & $-5.4 \pm 31.4$ & $<0.001$ \\
魚介類 & $(\mathrm{g})$ & $-6.0 \pm 17.2$ & $1.3 \pm 13.9$ & 0.24 \\
肉類 & $(\mathrm{g})$ & $-8.4 \pm 31.9$ & $7.3 \pm 41.7$ & 0.43 \\
卵類 & $(\mathrm{g})$ & $-11.2 \pm 14.4$ & $7.5 \pm 9.7$ & 0.003 \\
乳類 & $(\mathrm{g})$ & $36.9 \pm 97.2$ & $-11.6 \pm 56.0$ & 0.11 \\
\hline
\end{tabular}

值は平均值土標準偏差 $(n=14)$

$\dagger$ 対応のある $t$ 検定または Wilcoxon の符号付き順位和検定

変化量は減量期前の各值を共変量として調整した

$\mathrm{MCV}, \mathrm{MCH}, \mathrm{MCHC}$ それぞれの変化量は2009年度と 2010年度の間に有意な差はみられなかった。しかし, 体 脂肪率の変化量は2009年度と2010年度との間に有意な差 がみられ $(p=0.011), 2010$ 年度が有意に減少していた。 Ht の変化量は, 2009年度に比べて2010年度が有意に増加 した $(p=0.006)$ 。食物摂取状況では, エネルギーや鉄, 魚介類, 肉類, 乳類摂取量の変化量は2009年度と2010年 度の間に有意な差はみられなかったものの, たんぱく質 摂取量, たんぱく質エネルギー比率, 豆類および卵類摂 取量の変化量は2009年度と2010年度の間に有意な差がみ られ，いずれの摂取量も2010年度が2009年度に比べて有 意に増加していた。

\section{N. 考察}

本研究は大学女子新体操選手を対象にオフ期に 4 回に わたって「減量期のたんぱく質摂取量を低下させないこ と」をテーマにした栄養教育を行い, その効果を検証し た。その結果, オフ期の栄養教育は体脂肪率の減少と, 豆類や卵類，たんぱく質摂取量やたんぱく質エネルギー 比率の低下抑制につながる可能性が示唆された。この時,
Ht を除く貧血指標にはいずれの年度も減量期前後で有意 な違いはみられず，今回の栄養教育では貧血指標にまで 影響を及ぼすことはなかった。

新体操選手の練習内容はストレッチ, バーレッスン, 筋力トレーニング, 徒手運動からなる「基本練習」, 手具 操作を扱う「部分練習」, さらに演技の全体構成を確認す る「通し練習」で構成される。減量期の一日の平均練習 時間は 6 時間であり，結果には示していないが，2009年 度と2010年度の減量期間で有意な違いはみられなかった。 また，2009年度は減量期前後で体重，体脂肪率に有意な 差を認めなかったことから，減量期のエネルギー摂取量 は消費量との間にバランスが保たれていた可能性がある。 一方，2010年度は減量期前後の体重に有意な差はみられ なかったものの，体脂肪率は減量期前に比べて減量期後 が有意に低下していたことから，2010年度の減量期後は エネルギー消費量が増加した可能性が考えられた。この ことは対象選手の学年の進行に伴うエネルギー消費量の 増加が関連する可能性も考えられるが，今回はエネル ギー消費量の測定を行っていないため推測の域を出ない。

これまで我々は減量期の貧血予防のためのたんぱく質 摂取量は体重当たり $1.4 \mathrm{~g}$ が必要と報告してきた ${ }^{4)}$ 。今回 
の体重当たりたんぱく質摂取量は2009年度の減量期前が $1.36 \mathrm{~g}$, 減量期後が $1.18 \mathrm{~g}, 2010$ 年度では減量期前が $1.18 \mathrm{~g}$, 減量期後が $1.20 \mathrm{~g}$ であり, 両年度ともこれを下 回っていた。今回，貧血指標に有意な変化が見られな かった背景として，豆類や卵類摂取量，1日あたりのた んぱく質摂取量が増加したにも関わらず，その増加は少 なかったことが関わる可能性がある。なお，貧血予防に 求められるたんぱく質摂取量については今後とも更なる データの蓄積が必要と考えている。

今回の栄養教育の結果では, 豆類や卵類摂取量が減量 期に増加していた。一人暮らし大学生（男性300名, 女性 300名）をWEB 調査した全国農業協同組合中央会の報 告 $^{11)}$ によると, 一人暮らし大学生の 1 ケ月の食費は 20,301円とされている。また，一日に何食を自炊してい るかを尋ねた結果では 1 食が $34.1 \% ， 2$ 食が $36.5 \%$ あ り, 必ずしも全員が自炊をしているわけではなかった。 大学女子新体操選手の 1 ケ月の食費は約 25,000 円であり (未発表データ), 自炊はできない状況にあると報告され ている ${ }^{7)}$ 。減量期の新体操選手は 21 時過ぎまで練習を 行っており, 夕食の時刻は 22 時を過ぎることがほとんど である。そのため, 練習後に夕食を作ることは負担とな ることから, 選手はコンビニエンスストアやスーパー マーケットで惣菜類などの調理加工食品を買って食べる ことが多い。今回の教育の成果として, 減量期に摂取量 の増加がみられた豆類や卵は安価で栄養価が高く, 調理 にも手間がかからないことから, 選手にとって実生活に 取り入れやすい食品であったことが考えられた。

また，アスリートを対象とした栄養に関する知識の有 無と食物摂取状況との関わりを検討した報告を見ると， 両者の間に関連性はないとする報告 ${ }^{12)}$ と関連性があると する報告 ${ }^{13)}$ がある。Abood ら ${ }^{12)}$ は女性アスリート （サッカー選手15名, 水泳選手15名）を無作為に教育群 と対照群の 2 群に割り付け, 教育群にのみ栄養素の基礎 知識や適切な食品選択について講義形式による全 8 回の 栄養教育を実施した結果, 栄養教育は食知識を向上させ るが, 食物摂取量には有意な変化をもたらさないと報告 している。一方, Frederick ら ${ }^{13)}$ は大学女性アスリート (陸上競技, ダンサー), 一般女子大学生, 閉経後の女性 を対象に食知識があるものほどカルシウムを多く含む食 品の摂取頻度が高いことを報告している。今回, 我々は 食知識についての調査を行っていないため, 食知識が変 化した可能性についてはわからない。しかし, 調理実習 では食物や栄養に関する知識や調理技術の基礎的な知識 の習得が期待できることが報告されており ${ }^{8)}$ ，また，これ までの一過性の栄養教育では食物摂取状況にまで有意な
変化をもたらすことができなかったこと年）を考えると， 講義や買い物, 調理実習や献立作成といった体験学習と 継続的な支援活動が知識の獲得や減量期のたんぱく質摂 取量の低下抑制につながった可能性がある。今後とも, 減量期の食生活上の課題を解決する, 粘り強い継続的な 支援が必要と考えられた。

本研究の限界点は以下のとおりである。1 点目は, 本 研究では減量期の習慣的な摂取量を評価することを目的 としたため, 食物摂取状況の評価には食物摂取頻度調査 法を用いている。本研究で用いた食物摂取頻度調査票は 一般人を対象に開発されたものであり, 今回の対象者の ように食事時刻が不規則で，欠食などのムラのある食べ 方を日常的に繰り返す特殊な集団に対して用いることの 妥当性については不明であり, 本研究の限界である。ゆ えに, 今後はスポーツ選手を対象とした食物摂取頻度調 査票を開発する必要があるだろう。

2 点目は, 本研究ではエネルギー消費量の検討を行っ ていない。エネルギー消費量の推定には二重標識水法 （DLW 法）が最も精度の高いゴールドスタンダードとさ れている。しかし, 分析には特殊な機器を必要とし, 費 用が高いことなどから，研究の実施には多くの困難を伴 う。一方, 簡便にエネルギー消費量を推定する方法には, 加速度計法, 生活活動記録法, 心拍数法が挙げられる。 その中でも生活活動記録法はアスリートを対象とした測 定法として比較的優れた推定法であると報告されてい $ろ^{14)}$ 。しかし, 新体操の練習はストレッチ, バーレッス ン, 筋力トレーニング, 徒手運動からなる基本練習, 手 具操作を扱う部分練習, さらに, 演技の全体構成を確認 する通し練習など多岐にわたり，走る，投げる，跳躍な どの動作が混在している。それゆえ, 運動中の動作内容 を正確に把握すること, そして, エネルギー消費量を適 切に評価することが難しい。運動中のエネルギー消費量 を正確に評価することは今後の検討課題である。

3 点目は本研究では同じ選手を 2 年間にわたって追跡 しているが, 同時期に教育を行わないコントロール群を 設定できないことに限界がある。 2 年間の運動量や学年 の進行，選手の練習に対する意欲の変化など，様々な交 絡要因が食生活に影響した可能性が考えられることから, 対象者を教育群とコントロール群に分けて比較検討する 無作為化比較試験やクロスオーバー比較試験を行って教 育方法の有用性を検討する必要があると考えている。し かし，スポーツ選手が対象者となる場合，「試合に勝つ」 という明確な目標がある。それゆえ, 競技力に影響を与 える調査や研究のための介入試験は避けるべきであり, 許されることではない。試合に向けて同時期に介入群と 
コントロール群を設定することが難しいスポーツ選手で は， 2 年間の蓄積データを用いて栄養教育の効果を検証 できたことは重要な成果と考えている。

そして，たんぱく質摂取量と体内鉄栄養状態との関連 性については, 今後も年間トレーニング計画に対応させ つつデー夕を蓄積するとともに，選手自らがすすんで適 切な食品選択ができるようにするための教育プログラム の開発と栄養情報の提供, さらには継続的な支援が必要 である。

\section{V. 結 論}

大学女子新体操選手を対象にオフ期に減量期の貧血発 現予防のための食事改善を目的とした栄養教育を実施し， その効果を検討した。その結果, 減量期前に比べて減量 期後で, 教育前の2009年度はたんぱく質エネルギー比率, 豆類, 卵類摂取量が有意に減少したが, 教育後の 2010 年 度は体脂肪率が有意に減少し, 卵類摂取量は有意に増加 した。また, 減量期の変化量は, 教育を行った2010年度 が2009年度に比べて, 体脂肪率は有意に減少し, Ht, た んぱく質摂取量, たんぱく質エネルギー比率, 豆類や卵 類摂取量は有意に増加していた。このことから, 今回 我々がオフ期に複数回にわたって実施した栄養教育は, 減量期の Ht を除く貧血指標に影響を及ぼさないものの, 体脂肪率の低下とたんぱく質摂取量の低下抑制につな がった可能性が示唆された。

\section{謝辞}

本研究の実施にあたりご協力頂きました, 対象者の選 手の皆様並びに監督, コーチの方々に深く感謝申し上げ ます。

\section{利益相反}

利益相反に相当する事項はない。

\section{文献}

1）小清水孝子：スポーッと栄養一ジュニアからトップレ ベルの食事管理の実際—審美系女子スポーツ選手の減量 時の食事における問題点, 臨床スポーツ医学, 25, 891-
$896(2008)$

2）河野一郎：女子スポーツ選手の貧血の状況，臨床ス ポーツ医学, 6, 489-492 (1989)

3）目崎 登, 川崎彰子, 相澤勝治, 他：スポーツにおけ る体重コントロール 女子競技者の体重コントロールと 月経異常, 臨床スポーツ医学, 23, 377-381 (2006)

4）小久保友貴, 川野 因, 森佳子, 他: 大学女子新体 操選手の体内鉄栄養状態とたんぱく質摂取状況，体力科 学, 59, 475-483 (2010)

5）川野 因, 山田美恵子, 木皿久美子, 他：新体操選手 のスポーツ貧血発現予防を目的とした「肉料理教室」の 有効性, 食肉に関する助成研究調査成果報告書 Vol. 27, pp. 86-94（2009）財団法人伊藤記念財団，東京

6) 小久保友貴, 近藤珠里, 多田由紀, 他：女子新体操選 手を対象とした 2 カ月にわたる食教育の効果, 日本栄養 士会雑誌， 52, 1084-1092（2009）

7）石崎朔子, 木皿久美子, 川野 因：スポーツにおける 体重コントロール＼cjkstart新体操選手における体重コントロー ルの実際—減量に伴う貧血発現の検討一, 臨床スポーツ 医学, 23, 405-414 (2006)

8) Omori, K.: Relationships between Knowledge, Cooking Technique, Self-Efficacy and Behavior for Healthy Eating among Japanese Senior High School Students, J. Home. Econ.Jpn., 54, 993-1005 (2003)

9) Siri, W.E.: Body composition from fluid spaces and density. Analysis of method. In., J. Brozek, \& A. Henschel (eds.), Techniques for measuring body composition, pp. 223-244（1961） National Academy of Sciences National Research Council, Washington, DC.

10）高橋啓子, 吉村幸雄, 開元多恵, 他 : 栄養素および食 品群別摂取量推定のための食品群をべースとした食物捸 取頻度調査票の作成および妥当性, 栄養学雑誌, 59, 221-232 (2001)

11）全国農業協同組合中央会（JA 全中）：平成20年度朝ご はん実態調查 第 5 回, http://yoi-shoku.websozai.jp/ about/pdf/25.pdf, (2012年 8 月27日)

12) Abood, D.A., Black, D.R., Birnbaum, R.D.: Nutrition education intervention for college female athletes, J. Nutr. Educ. Behav., 36, 135-137 (2004)

13) Frederick, L., Hawkins, S.T.: A comparison of nutrition knowledge and attitudes, dietary practices, and bone densities of postmenopausal women, female college athletes, and nonathletic college women, J. Am. Diet. Assoc., 92, 299-305 (1992)

14）引原有輝, 斉藤慎一, 吉武 裕：高校野球選手におけ る簡易エネルギー消費量測定法の妥当性の検討, 体力科 学, 54, 363-372 (2005)

(受付：平成 24 年 5 月 1 日, 受理 : 平成 24 年 12 月 18 日) 


\title{
Effects of Off-season Nutritional Education on Dietary Improvement in Female Rhythmic Gymnasts during Weight Reduction Periods
}

\author{
Yuri Yokoyama*1, Mieko Yamada*2, Kumiko Kisara*2, Misuzu Hashizume*3,*4, \\ Yuki Kokubo*5, Azumi Hida*6, Yuki Tada*6, Takahiro Yoshizaki*1, \\ Ayaka Sunami*1, Sakuko Ishizaki*2 and Yukari Kawano*6 \\ ${ }^{* 1}$ Graduate School of Agriculture, Tokyo University of Agriculture \\ ${ }^{* 2}$ Faculty of Sports and Health Sciences, Japan Women's College of Physical Education \\ ${ }^{*}$ InaNishi High School \\ ${ }^{* 4}$ Matsumoto University Graduate School of Health Science \\ ${ }^{* 5}$ Department of Food and Nutritional Environment, College of Human Life and Environment, \\ Kinjo Gakuin University \\ ${ }^{* 6}$ Department of Nutritional Science, Faculty of Applied Bioscience, Tokyo University of Agriculture
}

\begin{abstract}
Objective: The present study aimed to investigate whether off-season nutritional education for female rhythmic gymnasts during their weight reduction periods might help prevent decreased protein intake and anemia.
\end{abstract}

Methods: Fourteen female rhythmic gymnasts participated in this study, which was conducted from Jun 2009 (before weight reduction) to Aug 2010 (after weight reduction). Nutritional education was provided during the off-season period (Feb-Apr 2010) and included lectures as well as classes on shopping, cooking, and menu planning. Physical characteristics and dietary intake were assessed four times in total before (Jun) and after (Aug) the weight reduction periods in both 2009 and 2010.

Results: No significant differences in physical characteristics, hematological values, and dietary intake were observed between 2009 and 2010 except in terms of body weight, body mass index, lean body weight, and red blood cell counts. There was a significant decrease in the protein-energy ratio and intake of beans and eggs in Aug 2009, and body fat in Aug 2010. In addition, egg intake was significantly higher in Aug 2010 than in Jun 2010. These results show that, compared to 2009, body fat changes during the weight reduction periods significantly decreased in 2010, whereas changes in hematocrit, intake of protein, beans and eggs, and protein-energy ratio significantly increased in 2010.

Conclusions: Off-season nutritional education for female rhythmic gymnasts during their weight reduction periods may help prevent decreased protein intake, but it does not seem to affect the iron status parameters, with the exception of the hematocrit level.

Jpn. J. Nutr. Diet., 71 (1) 29 36 (2013)

Key words: nutritional education, rhythmic gymnastics, weight reduction periods, protein intake, anemia 